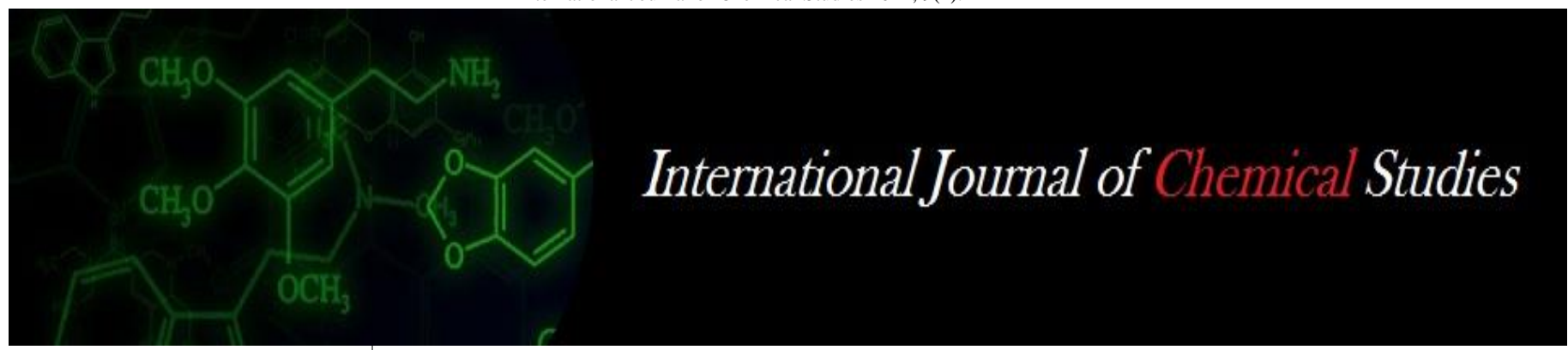

P-ISSN: 2349-8528

E-ISSN: 2321-4902

www.chemijournal.com

IJCS 2021; 9(1): 1121-1124

(C) 2021 IJCS

Received: 30-09-2020

Accepted: 02-12-2020

Yogesh

Department of Agronomy,

Indira Gandhi Krishi

Vishwavidyalaya, Raipur,

Chhattisgarh, India

SK Dwivedi

Department of Agronomy,

Indira Gandhi Krishi

Vishwavidyalaya, Raipur,

Chhattisgarh, India

\section{DK Chandrakar}

Department of Agronomy, Indira Gandhi Krishi

Vishwavidyalaya, Raipur, Chhattisgarh, India
Corresponding Author:

Yogesh

Department of Agronomy,

Indira Gandhi Krishi

Vishwavidyalaya, Raipur,

Chhattisgarh, India

\section{Effect of varieties and nutrient levels on seed yield, oil yield and total nutrient uptake of sesame (Sesamum indicum L.)}

\author{
Yogesh, SK Dwivedi and DK Chandrakar
}

DOI: https://doi.org/10.22271/chemi.2021.v9.i1p.11373

\section{Abstract}

The experiment was conducted at Research Cum Instructional Farm of IGKV, Raipur, Chhattisgarh, The crop was sown during Kharif season of 2019. The soil condition of experimental field was clay in texture (vertisols). The experiment was laid out in strip plot design with treatments viz. vertical strips consisted three sesame varieties $\left(\mathrm{V}_{1}\right.$ : TKG-22, $\mathrm{V}_{2}$ : TKG-308 and $\mathrm{V}_{3}$ : JTS-8) and horizontal strip consisted four nutrient levels $\left(\mathrm{N}_{1}: 75 \% \mathrm{RDF}, \mathrm{N}_{2}: 100 \% \mathrm{RDF}, \mathrm{N}_{3}: 125 \%\right.$ RDF and $\mathrm{N}_{4}: 150 \%$ RDF) with 12 treatment combinations and replicated thrice. The recommended dose of fertilizer (RDF) is 30:30:20:20 N, $\mathrm{P}_{2} \mathrm{O}_{5}$, $\mathrm{K}_{2} \mathrm{O}$ and $\mathrm{S} \mathrm{kg} \mathrm{ha}{ }^{-1}$, respectively. Result revealed that among the varieties significantly maximum number of capsules plant ${ }^{-1}$, seeds capsule ${ }^{-1}$, test weight, seed yield, stover yield, oil content and oil yield were found in variety JTS-8, which was at par with TKG-22 with respect to seeds capsule ${ }^{-1}$ and stover yield, it was also at par with TKG-308 with respect to oil content. Above parameters were found minimum(except test weight) in variety TKG-308, maximum N, P, S uptake was found in variety JTS-8 and minimum was found in variety TKG-308, while maximum $\mathrm{K}$ uptake was found in variety TKG-22 and minimum in JTS-8. In case of nutrient levels highest number of capsules plant ${ }^{-1}$, seeds capsule ${ }^{-1}$, test weight, seed yield, stover yield, oil content, oil yield and nutrient uptake (N, P, K and S) were observed with the application of $150 \%$ RDF, which was at par with $125 \%$ RDF with respect to number of seeds capsule $^{-1}$, seed yield, stover yield, oil yield. The data from interaction effect of varieties and nutrient levels, the maximum seed yield was obtained with the combination of JTS-8 $\left(\mathrm{V}_{3}\right)+150 \%$ RDF $\left(\mathrm{N}_{4}\right)$.

Keywords: Nutrient levels, nutrient uptake, sesame, varieties, yield attributes and yield

\section{Introduction}

Sesame is one of the major oilseed crops in India. There are three known cultivars of sesame seeds like white, black and red (Jain et al. 2015) ${ }^{[5]}$ and it is also called queen of oilseeds and poor man's substitute for ghee. The area, production and productivity of sesame in India during 2018-19 is 1.60 million hectare, 0.76 million tonnes and $473 \mathrm{~kg} \mathrm{ha}^{-1}$, respectively and in Chhattisgarh the area, production and productivity of sesame during 2017-18 is 24.92 thousand ha, 8.37 thousand tonnes and $336 \mathrm{~kg} \mathrm{ha}^{-1}$, respectively. In India the largest producer of sesame is Gujarat, it contributes $22.3 \%$ of total production, followed by $19.2 \%$ (West Bengal), $13.5 \%$ (Karnataka), 9.8\% (Rajasthan), 9.06\% (M.P), and 4.7\% (Tamil Nadu), $4.52 \%$ (A.P.) and $4.52 \%$ (Maharashtra) (Anonymous, 2019) ${ }^{[1]}$.

Variety plays an important role on sesame yield and quality. Variations in seed yield due to varietal potential have already been reported (Raja et al. 2007 and Mohsana, 2009) ${ }^{[9,8]}$. The seed yield of sesame crop is significantly affected by varieties or cultivars (Hazarika, 1998) ${ }^{[4]}$. The nutritional requirement of sesame is controversial since long time (Okpara et al. 2007) ${ }^{[6]}$, while most research scientists trusted that sesame does not need any fertilization, some thought that the crop required fertilization. Proper nitrogen supply is beneficial to carbohydrates and protein metabolism, facilitating cell division and cell enlargement. Similarly, good phosphorus supply is normally associated with increased growth characters, therefore ensuring higher yield of seed and dry matter (Maiti and Jana 1985) ${ }^{[7]}$.

The requirement of sulphur is equal to phosphorus (Scherer 2001) ${ }^{[11]}$, If the soil contain low amount of available $\mathrm{K}$, it is advised to apply $15-30 \mathrm{~kg}$ potassium ha ${ }^{-1}$ to maintain the proper nutritional balance of sesame (Sharma 1997) ${ }^{[10]}$. Sulphur play important role in the plant metabolism, sulphur helps flower initiation in sesame which ultimately increases the number 
of capsules plant ${ }^{-1}$ and seeds capsule ${ }^{-1}$, sulphur also increases the oil content of sesame crops (Hassan et al. 2007). Hence balance nutrition is important for any crop as well as soil health.

\section{Materials and methods}

The experiment was conducted at research cum instructional farm of IGKV, Raipur Chhattisgarh, Raipur is situated in the central Chhattisgarh plain at $21^{\circ} 4^{\prime} \mathrm{N}$ latitude and $81^{\circ} 35^{\prime} \mathrm{E}$ longitude at the height of $290.20 \mathrm{~m}$ above the mean sea lined (MSL). The soil condition of experimental field was clayey in texture (vertisols), the soil contained low amount of nitrogen, high phosphorus, medium potassium and low amount of sulphur $\left(225.96,20.83,283.24\right.$ and $10.29 \mathrm{~kg} \mathrm{ha}^{-1}, \mathrm{~N}, \mathrm{P}, \mathrm{K}$ and $\mathrm{S}$, respectively). The experiment was laid out in strip plot design viz. vertical strips consisted three sesame varieties $\left(\mathrm{V}_{1}\right.$ : TKG-22, $\mathrm{V}_{2}$ : TKG-308 and $\mathrm{V}_{3}$ : JTS-8) and horizontal strip consisted four nutrient levels $\left(\mathrm{N}_{1}: 75 \% \mathrm{RDF}, \mathrm{N}_{2}: 100 \% \mathrm{RDF}\right.$, $\mathrm{N}_{3}: 125 \%$ RDF and $\mathrm{N}_{4}: 150 \%$ RDF) with 12 treatment combinations and replicated thrice. The recommended dose of fertilizer (RDF) is 30:30:20:20 kg N, $\mathrm{P}_{2} \mathrm{O}_{5}, \mathrm{~K}_{2} \mathrm{O}$ and $\mathrm{S} \mathrm{ha}{ }^{-1}$, respectively. The Crop was sown during kharif season of 2019. The Urea, single super phosphate, murate of potash and zinc sulphate was used as a source for nitrogen, phosphorus, potassium and sulphur, respectively.

After the harvesting of crop, already tagged five plants were used for counting number of capsules plant ${ }^{-1}$ and their mean was calculated, at the time of threshing ten capsules randomly selected from the five sample plants from each treatment and then their seed was counted and mean was calculate. From the lot of threshed clean seeds of each plot, random seed sample was taken and one thousand seeds were counted. Then the weight of seeds of each treatment was recorded on an electronic balance.

The produce of each plot was threshed separately treatment wise and then seeds were cleaned. The weight of clean seeds obtained from each plot was recorded on weighing balance finally the seed yield was converted into yield $\mathrm{kg} \mathrm{ha}^{-1}$ by multiplying with appropriate conversion factor. Stover yield determined by subtracting the seed yield from the biological yield of each net plot under a particular treatment and harvest index was calculated as suggested by Donald $1962^{[2]}$.

$\mathrm{HI}(\%)=\frac{\text { Seed yield }\left(\mathrm{kg} \mathrm{ha}^{-1}\right)}{\text { Biological yield }\left(\mathrm{kg} \mathrm{ha}^{-1}\right)} \times 100$

The oil content of seeds was estimated by using Socs plus equipment. The oil yield determined by following formula.

$$
\text { Oil yield }\left(\mathrm{kg} \mathrm{ha}^{-1}\right)=\frac{\text { Oil\% in seed } \times \text { seed yield }\left(\mathrm{kg} \mathrm{ha}^{-1}\right)}{100}
$$

The nutrient uptake was calculated by following formula

$$
\text { Nutrient uptake }\left(\mathrm{kg} \mathrm{ha}^{-1}\right)=\frac{\text { Nutrient concentration in plant }(\%) \times \text { yield }\left(\mathrm{kg} \mathrm{ha}^{-1}\right)}{100}
$$

\section{Results and Discussion \\ Effect of variety}

The effect of varieties was found significant on yield attributes, seed yield, stover yield, oil content and oil yield of sesame. The variety JTS- $8\left(\mathrm{~V}_{3}\right)$ found significantly superior with respect to number of capsules plant ${ }^{-1}$ (46.87) as compare to other varieties of sesame and minimum number of capsules plant $^{-1}$ (43.73) was observed in variety TKG-308 $\left(\mathrm{V}_{2}\right)$. The maximum number of seeds capsule ${ }^{-1}(59.03)$ was recorded in variety JTS-8 $\left(\mathrm{V}_{3}\right)$, which was found at par with TKG-22 $\left(\mathrm{V}_{1}\right)$ and minimum number of seeds capsule ${ }^{-1}$ was recorded in variety TKG-308. Throve et al. (2011) ${ }^{[12]}$ also reported varietal effect on capsules plant ${ }^{-1}$ and number of seeds capsule $^{-1}$ of sesame. The effect of varieties on test weight failed to give significant difference. The highest test weight $(3.36 \mathrm{~g})$ was recorded in variety JTS-8 $\left(\mathrm{V}_{3}\right)$ and lowest test weight $(3.22 \mathrm{~g})$ was observed in variety TKG-22 (Table 1). The highest seed yield $\left(849.17 \mathrm{~kg} \mathrm{ha}^{-1}\right)$, stover yield $(1554.58$ $\left.\mathrm{kg} \mathrm{ha}^{-1}\right)$ and harvest index $(35.32 \%)$ was recorded in variety JTS-8 ( $\left.\mathrm{V}_{3}\right)$ and it was found at par with variety TKG-22 ( $\left.\mathrm{V}_{1}\right)$ with respect of stover yield, the lowest seed, stover yield and harvest index was observed in variety TKG-308 $\left(\mathrm{V}_{2}\right)$.

The maximum oil content $(37.44 \%)$ and oil yield $(318.62 \mathrm{~kg}$ $\left.\mathrm{ha}^{-1}\right)$ was observed in variety JTS-8 $\left(\mathrm{V}_{3}\right)$ and it was found statistically at par with TKG-308 $\left(\mathrm{V}_{2}\right)$ with respect of oil content $(36.51 \%)$ and minimum oil content $(35.23 \%)$ was recorded in variety TKG-22 $\left(\mathrm{V}_{1}\right)$ and lowest oil yield found in variety TKG-308 $\left(\mathrm{V}_{2}\right)$. On the basis of these data variety JTS8 gives $20.97,12.77$ and $23.76 \%$ more seed yield, stover yield and oil yield, respectively as compare to TKG-308. While variety TKG-22 gives 9.16, 8.15 and 5.36\% more seed, stover and oil yield, respectively as compare to TKG-308. The total uptake of nitrogen differ significantly and the total uptake of phosphorus, potassium and sulphur differ non significantly due to varieties (Table 2), total uptake of $\mathrm{N}, \mathrm{P}$ and $\mathrm{S}$ was found maximum in variety JTS- 8 and the minimum total $\mathrm{N}, \mathrm{P}$ and $\mathrm{S}$ uptake was found in variety TKG-308 $\left(\mathrm{V}_{2}\right)$, while the total $\mathrm{K}$ uptake $\left(13.41 \mathrm{~kg} \mathrm{ha}^{-1}\right)$ was found maximum in variety TKG-22 $\left(\mathrm{V}_{1}\right)$ and minimum in variety JTS-8 $\left(\mathrm{V}_{3}\right)$ (Table 2$)$.

\section{Effect of nutrient levels}

Significant difference was found among the nutrient levels with respect of yield attributes, seed yield, stover yield, oil content, oil yield and nutrient uptake of sesame (Table 1 and $2)$. The application of $150 \%$ RDF $\left(\mathrm{N}_{4}\right)$ significantly produced maximum number of capsules plant ${ }^{-1}(50.87)$ and number of seeds capsule ${ }^{-1}(61.04)$ as compare to other nutrient levels, $\mathrm{N}_{4}$ was at par with $\mathrm{N}_{3}$ with respect of number of seeds capsule ${ }^{-1}$ (58.51), however $\mathrm{N}_{4}$ was also found at par with $\mathrm{N}_{2}$ with respect of number of seeds capsule ${ }^{-1}$ (56.22). While the minimum number of capsule plant $^{-1}$ and number of seeds capsule $^{-1}$ was recorded under $75 \% \operatorname{RDF}\left(\mathrm{N}_{1}\right)$. Among nutrient levels no significant difference was observed on test weight, though the highest test weight $(3.31 \mathrm{~g})$ was observed with the application of $150 \% \mathrm{RDF}\left(\mathrm{N}_{4}\right)$ and lowest test weight (3.24 g) was observed with the application of $75 \% \operatorname{RDF}\left(\mathrm{N}_{1}\right)$.

Application of $150 \%$ RDF $\left(\mathrm{N}_{4}\right)$ significantly produced maximum seed $\left(859.56 \mathrm{~kg} \mathrm{ha}^{-1}\right)$, stover yield $\left(1592.89 \mathrm{~kg} \mathrm{ha}^{-}\right.$ $\left.{ }^{1}\right)$, oil content $(38.68 \%)$ and oil yield $\left(332.97 \mathrm{~kg} \mathrm{ha}^{-1}\right)$, respectively and it was found statistically at par with $\mathrm{N}_{3}$ with respect of seed $\left(812.22 \mathrm{~kg} \mathrm{ha}^{-1}\right)$, Stover $\left(1550.22 \mathrm{~kg} \mathrm{ha}^{-1}\right)$ and oil yield $\left(297.57 \mathrm{~kg} \mathrm{ha}^{-1}\right), \mathrm{N}_{4}$ also at par with $\mathrm{N}_{2}$ with respect to seed yield, above parameters were found minimum under $75 \% \operatorname{RDF}\left(\mathrm{N}_{1}\right)$. The total uptake of $\mathrm{N}, \mathrm{P}, \mathrm{K}$ and $\mathrm{S}$ was differs significantly (except $\mathrm{K}$ ) due to nutrient levels (Table 2). Among nutrient levels, the maximum total nitrogen uptake (37.62 $\left.\mathrm{kg} \mathrm{ha}^{-1}\right)$, total $\mathrm{P}$ uptake $\left(24.66 \mathrm{~kg} \mathrm{ha}^{-1}\right)$, total $\mathrm{K}$ uptake $\left(14.49 \mathrm{~kg} \mathrm{ha}^{-1}\right)$ and maximum total $\mathrm{S}$ uptake $\left(9.67 \mathrm{~kg} \mathrm{ha}^{-1}\right)$ was observed with the application of $150 \%$ RDF $\left(\mathrm{N}_{4}\right)$, which was statistically at par with $\mathrm{N}_{3}$ with respect of total $\mathrm{P}$ uptake (22.64 $\left.\mathrm{kg} \mathrm{ha}^{-1}\right)$, while the minimum total nitrogen, phosphorus, potassium and sulphur uptake was observed with the application of $75 \% \operatorname{RDF}\left(\mathrm{N}_{1}\right)$. 


\section{Interaction effect}

Significant difference on seed yield was observed due to interaction effect of varieties and nutrient levels and data are presented in table 3. The interaction indicates varieties were positively influenced with the application of different nutrient levels. Among various treatment combinations, the maximum seed yield $\left(914.67 \mathrm{~kg} \mathrm{ha}^{-1}\right)$ was obtained from the treatment combination of variety JTS-8 $\left(\mathrm{V}_{3}\right)$ and $150 \% \mathrm{RDF}\left(\mathrm{N}_{4}\right)$ and the minimum seed yield $\left(574.67 \mathrm{~kg} \mathrm{ha}^{-1}\right)$ was obtained from treatment combination of TKG-308 and 75\% RDF.

Table 1: Yield attributes and yield of sesame as influenced by varieties and nutrient levels

\begin{tabular}{|c|c|c|c|c|c|c|c|c|}
\hline Treatments & $\begin{array}{l}\text { No. of capsules } \\
\text { plant }^{-1}\end{array}$ & $\begin{array}{l}\text { No. of seeds } \\
\text { capsule }^{-1}\end{array}$ & $\begin{array}{c}\text { Test weight } \\
\text { (g) }\end{array}$ & $\begin{array}{c}\text { Seed yield } \\
\left(\mathrm{kg} \mathrm{ha}^{-1}\right)\end{array}$ & $\begin{array}{c}\text { Stover yield } \\
\left(\mathrm{kg} \mathrm{ha}^{-1}\right)\end{array}$ & $\begin{array}{c}\text { Harvest } \\
\text { index }(\%)\end{array}$ & $\begin{array}{c}\text { Oil content } \\
(\%)\end{array}$ & $\begin{array}{l}\text { Oil yield } \\
\left(\mathrm{kg} \mathrm{ha}^{-1}\right)\end{array}$ \\
\hline \multicolumn{9}{|l|}{ Varieties } \\
\hline $\mathrm{V}_{1}: \mathrm{TKG}-22$ & 44.57 & 57.07 & 3.22 & 766.25 & 1490.83 & 33.94 & 35.23 & 271.23 \\
\hline $\mathrm{V}_{2}: \mathrm{TKG}-308$ & 43.73 & 55.28 & 3.25 & 701.92 & 1378.42 & 33.74 & 36.51 & 257.43 \\
\hline $\mathrm{V}_{3}: \mathrm{JTS}-8$ & 46.87 & 59.03 & 3.36 & 849.17 & 1554.58 & 35.32 & 37.44 & 318.62 \\
\hline S.Em \pm & 0.53 & 0.70 & 0.10 & 20.96 & 33.58 & - & 0.39 & 7.19 \\
\hline $\mathrm{CD}(\mathrm{P}=0.05)$ & 2.07 & 2.77 & NS & 80.97 & 131.86 & - & 1.52 & 28.23 \\
\hline \multicolumn{9}{|l|}{ Nutrient levels } \\
\hline $\mathrm{N}_{1}: 75 \% \mathrm{RDF}$ & 39.56 & 52.73 & 3.24 & 657.33 & 1368.67 & 32.44 & 34.07 & 223.78 \\
\hline $\mathrm{N}_{2}: 100 \% \mathrm{RDF}$ & 43.51 & 56.22 & 3.27 & 760.67 & 1386.67 & 35.42 & 36.21 & 275.38 \\
\hline $\mathrm{N}_{3}: 125 \%$ RDF & 46.29 & 58.51 & 3.28 & 812.22 & 1550.22 & 34.38 & 36.62 & 297.57 \\
\hline $\mathrm{N}_{4}: 150 \% \mathrm{RDF}$ & 50.87 & 61.04 & 3.31 & 859.56 & 1592.89 & 35.06 & 38.68 & 332.97 \\
\hline S.Em \pm & 0.78 & 1.57 & 0.08 & 31.72 & 51.97 & - & 0.43 & 10.83 \\
\hline $\mathrm{CD}(\mathrm{P}=0.05)$ & 2.70 & 5.45 & NS & 109.76 & 179.84 & - & 1.50 & 37.47 \\
\hline \multicolumn{9}{|c|}{ Int $(\mathbf{V x N})$} \\
\hline S.Em \pm & 1.80 & 1.97 & 0.25 & 35.15 & 131.83 & - & 0.68 & 15.24 \\
\hline $\mathrm{CD}(\mathrm{P}=0.05)$ & - & NS & NS & 108.31 & NS & - & NS & NS \\
\hline
\end{tabular}

Table 2: Nutrient uptake of sesame as influenced by varieties and nutrient levels

\begin{tabular}{|c|c|c|c|c|}
\hline Treatments & $\begin{array}{c}\text { Total Nitrogen uptake } \\
\left(\mathrm{Kg} \mathrm{ha}^{-1}\right)\end{array}$ & $\begin{array}{c}\text { Total phosphorus uptake } \\
\left(\mathrm{Kg} \mathrm{ha}^{-1}\right)\end{array}$ & $\begin{array}{c}\text { Total potassium uptake } \\
\left(\mathrm{Kg} \mathrm{ha}^{-1}\right)\end{array}$ & $\begin{array}{c}\text { Total sulphur uptake } \\
\left(\mathrm{Kg} \mathrm{ha}^{-1}\right)\end{array}$ \\
\hline \multicolumn{5}{|c|}{ Varieties } \\
\hline $\mathrm{V}_{1}:$ TKG-22 & 32.66 & 20.36 & 13.41 & 6.79 \\
\hline $\mathrm{V}_{2}: \mathrm{TKG}-308$ & 29.73 & 19.68 & 12.79 & 5.59 \\
\hline $\mathrm{V}_{3}:$ JTS-8 & 36.87 & 23.80 & 11.69 & 8.00 \\
\hline $\mathrm{S} . \mathrm{Em} \pm$ & 1.35 & 1.57 & 0.53 & 0.55 \\
\hline $\mathrm{CD}(\mathrm{P}=0.05)$ & 5.29 & $\mathrm{NS}$ & $\mathrm{NS}$ & $\mathrm{NS}$ \\
\hline \multicolumn{5}{|c|}{ Nutrient levels } \\
\hline $\mathrm{N}_{1}: 75 \% \mathrm{RDF}$ & 27.91 & 17.17 & 10.97 & 4.11 \\
\hline $\mathrm{N}_{2}: 100 \%$ RDF & 31.88 & 20.64 & 11.53 & 5.96 \\
\hline $\mathrm{N}_{3}: 125 \% \mathrm{RDF}$ & 34.93 & 22.64 & 13.23 & 7.43 \\
\hline $\mathrm{N}_{4}: 150 \% \mathrm{RDF}$ & 37.62 & 24.66 & 14.49 & 9.67 \\
\hline S.Em \pm & 0.67 & 0.78 & 0.78 & 0.12 \\
\hline $\mathrm{CD}(\mathrm{P}=0.05)$ & 2.33 & 2.70 & $\mathrm{NS}$ & 0.42 \\
\hline \multicolumn{5}{|c|}{ Int (VXN) } \\
\hline S.Em \pm & 2.36 & 2.38 & 1.22 & 0.79 \\
\hline $\mathrm{CD}(\mathrm{P}=0.05)$ & $\mathrm{NS}$ & $\mathrm{NS}$ & NS & $\mathrm{NS}$ \\
\hline
\end{tabular}

Table 3: Interaction between varieties and nutrient levels on seed yield $\left(\mathrm{Kg} \mathrm{ha}^{-1}\right)$ of sesame

\begin{tabular}{|c|c|c|c|c|c|}
\hline \multirow[t]{2}{*}{ Varieties } & \multicolumn{5}{|c|}{ Nutrient levels } \\
\hline & $\mathbf{N}_{1}$ & $\mathbf{N}_{2}$ & $\mathbf{N}_{3}$ & $\mathbf{N}_{4}$ & Mean \\
\hline $\mathrm{V}_{1}$ & 575.00 & 799.33 & 829.00 & 861.67 & 766.25 \\
\hline $\mathrm{V}_{2}$ & 574.67 & 657.00 & 773.67 & 802.33 & 701.92 \\
\hline $\mathrm{V}_{3}$ & 822.33 & 825.67 & 834.00 & 914.67 & 849.17 \\
\hline Mean & 657.33 & 760.67 & 812.22 & 859.56 & \\
\hline \multirow{2}{*}{\multicolumn{4}{|c|}{$\begin{array}{l}\text { Two horizontal strip at the same level of } \\
\text { vertical strip }\end{array}$}} & S.Em \pm & $\mathrm{CD}(\mathrm{P}=0.05)$ \\
\hline & & & & 42.78 & 140.73 \\
\hline \multicolumn{4}{|c|}{$\begin{array}{l}\text { Two vertical strip at the same level of } \\
\text { horizontal strip }\end{array}$} & 36.77 & 123.07 \\
\hline
\end{tabular}

\section{Conclusion}

On the basis of yield attributes, seed yield, stover yield, oil content and oil yield were found superior with the variety JTS-8 among all the varieties, it was found at par with TKG22 with respect of number of seeds capsule ${ }^{-1}$ and stover yield. While in case of nutrient levels the application of $150 \%$ RDF $\left(\mathrm{N}_{4}\right)$ was found superior performance in terms of yield attributes, yield, oil content, oil yield and nutrient uptake, however it was found at par with the application of $125 \%$ RDF $\left(\mathrm{N}_{3}\right)$ in case of seeds capsule ${ }^{-1}$, seed yield, Stover yield and oil yield. The combination of variety JTS-8 and $150 \%$ RDF gives highest seed yield.

\section{References}

1. Anonymous. Ministry of agriculture \& farmer's welfare, Govt of India 2019.

2. Donald CM. In search of yield. J Aust. Intst. Agri. Sci 1962;28:171-178.

3. Hassan F, Hakim S, Qadir G, Ahmad S. Response of sunflower (Helianthus annuus L.) to sulphur and seasonal variations. Int. J Agri. and Bio 2007;9(3):499-503.

4. Hazarika DK. Influence of sowing date and varieties on development of powdery mildew of sesame in Assam. J Phyto. Res 1998;11:73-75.

5. Jain R, Grover K, Singla N. Oilseeds for better health, J Nut Res 2015;3(1):50-53. 
6. Okpara DA, Muoneke CO, Ojikpong TO. Effect of nitrogen and phosphorus fertilizer rates on the growth and yield of sesame (Sesamum indicum L.) In the southeastern rainforest belt of Nigeria. Nigerian Agriculture Journal 2007;38:1-11.

7. Maiti D, Jana PK. Effect of different levels of $\mathrm{N}$ and $\mathrm{P}$ on yield and yield attributes of sesamum. Journal of Oil seeds Research 1985;(2):252-259.

8. Mohsana A. Effect of different levels of sulphur and boron on the yield and oil content of sesame. M.S. Thesis, Dept. Agron. Bangladesh Agril. Univ. Mymensingh 2009, 43-48.

9. Raja A, Hattab OK, Gurusamy L, Suganya S. Sulphur levels on nutrient uptake and yield of sesame varieties and nutrient availability. International Journal of Soil Science 2007;2:278-285.

10. Sharma SM. Efficient management of dry land crop in India. Journal of Oilseed Research 1997, 192-227.

11. Scherer HW. Sulphur in crop production. Eur. J Agron 2001;14:81-111.

12. Thorve SB, Katwate MT, Jadhav JD. Response of sesamum (Sesamum indicum L.) cultivars under varying levels of fertilizers under rainfed conditions. Asian Journal of Soil Science 2011;6(1):1-10. 